\title{
Short communication: Barrier characteristics of 3 external teat sealants to prevent bacterial penetration under in vitro conditions using rubber calf-feeding nipples
}

\author{
S. Piepers, ${ }^{*}$ I. Van Den Brulle, K. Mertens, and S. De Vliegher \\ M-team and Mastitis and Milk Quality Research Unit, Department of Reproduction, Obstetrics and Herd Health, Faculty of Veterinary Medicine, \\ Ghent University, 9820 Merelbeke, Belgium
}

\begin{abstract}
The main objective of this study was to evaluate the barrier characteristics of 3 external teat sealants for dry cows in preventing bacterial penetration by 3 common major mastitis pathogens (Escherichia coli, Staphylococcus aureus, and Streptococcus uberis) via a novel in vitro simulation model using rubber calffeeding nipples. All feeding nipples were filled with a sterile cotton plug soaked in sterile broth heart infusion medium and were treated as follows: rubber teats 1 and 5 were sealed with Ubera Dry (Inovet, Arendonk, Belgium); rubber teats 2 and 6 were sealed with THexx Dry (Huvepharma Livestock, St. Louis, MO); rubber teats 3 and 7 were sealed with Uddergold Dry (Ecolab Food and Beverage Division, St. Paul, MN); and rubber teats 4 and 8 remained unsealed and served as positive and negative controls, respectively. After the dips had dried, rubber teats 1 to 4 were immersed in a suspension of E. coli (experiment 1), Staph. aureus (experiment 2), or Strep. uberis (experiment $3 ; \geq 1.5 \times 10^{8}$ $\mathrm{cfu} / \mathrm{mL}$ ) for $24 \mathrm{~h}$, whereas rubber teats 5 to 8 were not exposed to the bacterial suspensions. All external teat sealants adhered well to the rubber teats. All cotton plugs collected from the teats that were not exposed to E. coli, Staph. aureus, or Strep. uberis (rubber teats 5 to 8) remained culture-negative, except for 1 (due to contamination). Of the rubber teats that were exposed to the major mastitis pathogens, all cotton plugs collected from the teats dipped with Ubera Dry and T-Hexx Dry remained culture-negative for the mastitis pathogen they were exposed to. The cotton plugs of the rubber teats that were sealed with Uddergold Dry and exposed to E. coli and Strep. uberis showed positive cultures for the respective bacteria, as demonstrated using straintyping. The cotton plugs collected from the rubber
\end{abstract}

Received September 11, 2019.

Accepted February 10, 2020.

*Corresponding author: Sofie.Piepers@UGent.be teats that were not sealed with an external teat sealant and that served as positive controls became culturepositive for the mastitis pathogens they were exposed to. We conclude that Ubera Dry showed comparable and superior barrier performance against penetration of E. coli, Staph. aureus, and Strep. uberis compared with T-Hexx Dry and Uddergold Dry, respectively, under in vitro conditions using a novel in vitro simulation model. Although one should be aware that the method has not yet been validated to predict risk of intramammary infections, the proposed technique can be a meaningful starting point to evaluate and compare the barrier characteristics of external teat sealants in preventing bacterial penetration. A large-scale clinical trial is needed before any definite conclusions can be drawn as to the adherence, duration of adherence, barrier performance, and efficacy in protection against intramammary infections of the 3 external teat sealants under field conditions.

Key words: external teat sealant, in vitro, dry period

\section{Short Communication}

The dry period is known as a most crucial yet ambivalent period for udder health in a cow's lactation cycle. The steady-state phase offers an excellent opportunity for curing existing IMI, whereas the involution and colostrogenesis phases are, conversely, periods of high risk for contracting new IMI (Bradley and Green, 2010). The risk of new IMI during the dry period is up to 10 times higher than the rate of new IMI during lactation, with a peak around involution of the mammary gland just after drying off and during the transition from pregnancy to lactation (Smith et al., 1985; Bradley et al., 2015). Internal teat sealants are well introduced on modern dairy farms. They are used as standalone products in noninfected cows or quarters in cases of selective dry-cow therapy or in combination with long-acting antibiotics to provide protection beyond that achieved through antibiotics alone (Halasa et al., 2009). Internal teat sealants function as inert 
physical barriers in the teat cistern, with the goal of preventing penetration of bacteria from the environment into the udder during the entire dry period. Cows can also be protected against new IMI during the dry period through use of external teat sealants (Lim et al., 2007a). When an external teat sealant is used, an artificial polymer or latex skin is put on the teat, usually via teat-dipping. In contrast to internal teat sealants, external teat sealants tend not to persist on the teat for more than a few days or weeks. Still, this might be enough to protect the mammary gland in the first days after dry-off, a high-risk period for new IMI (Lim et al., 2007a), but not later. A major advantage of external versus internal teat sealants is that use of an external teat sealant will reduce the risk of damage to the teat canal or accidental introduction of pathogens (Godden et al., 2003). Remarkably, except for the study of Lim et al. (2007a), no reports on the use and effects of external teat sealants during the dry period are available in peer-reviewed literature to our knowledge.

The main objective of this study was to evaluate the barrier characteristics of 3 external teat sealants for dry cows in preventing bacterial penetration by 3 common major mastitis pathogens (Escherichia coli, Staphylococcus aureus, and Streptococcus uberis) using a novel in vitro model with rubber calf-feeding nipples.

Three separate in vitro experiments were conducted in the laboratory of the Mastitis and Milk Quality Research Unit of Ghent University (Department of Reproduction, Obstetrics and Herd Health, Faculty of Veterinary Medicine, Merelbeke, Belgium). The barrier characteristics of a newly developed and available external teat sealant, Ubera Dry (Inovet, Arendonk, Belgium) for preventing bacterial penetration by the major mastitis pathogens Staph. aureus, Strep. uberis, and $E$. coli were evaluated under in vitro conditions by use of rubber calf-feeding nipples (Yuancheng, YCP97, Shandong, China; hereafter referred to as "rubber teats") and compared with 2 other commercially available barrier-type teat dips for dry cows: T-Hexx Dry Teat Sealant (Huvepharma Livestock, St. Louis, MO) and Uddergold Dry (Ecolab Food and Beverage Division, St. Paul, MN). Before the experiments, a hole was drilled in each rubber teat with a diameter of 1.5 $\mathrm{mm}$, to mimic the teat orifice and teat canal, and the 24 rubber teats were subjected to plasma sterilization at $35^{\circ} \mathrm{C}$ for $52 \mathrm{~min}$.

Separate experiments were conducted for each of the 3 major mastitis pathogens, using 8 rubber teats per mastitis pathogen. In each experiment, all rubber teats were first filled with $1 \mathrm{~g}$ of sterile cotton plug soaked in $19 \mathrm{~g}$ of sterile broth heart infusion (BHI) medium (Oxoid, Basingstoke, UK). Before use, the cotton plugs were autoclaved for $4 \mathrm{~h}$ at $135^{\circ} \mathrm{C}$. The cotton plug soaked in sterile BHI (total weight $20 \mathrm{~g}$ ) was gently pushed to the bottom of the rubber calf-feeding nipples. Subsequently, another $2 \mathrm{~mL}$ of BHI medium was drenched on the cotton plug. This step was repeated 2 more times. Finally, another small $(0.25 \mathrm{~g})$ sterile cotton plug was added on top of the first cotton plug, and $1 \mathrm{~mL}$ of BHI medium was drenched on top of the second cotton plug 2 times.

The rubber teats were treated as follows: rubber teats 1 and 5 were sealed with Ubera Dry; rubber teats 2 and 6 were sealed with T-Hexx Dry Teat Sealant; rubber teats 3 and 7 were sealed with Uddergold Dry; and rubber teats 4 and 8 remained unsealed, serving as positive and negative controls, respectively (Table 1). When retracting the rubber teats from the teat sealant, each teat was rotated to make sure the orifice was properly sealed, at least visually. In all cases, the teat sealant was air-dried in a laminar flow for $10 \mathrm{~min}$. After the dips had dried, the first $2 \mathrm{~cm}$ of rubber teats 1 to 4 were immersed in a bacterial suspension of $\geq 1.5 \times 10^{8}$ $\mathrm{cfu} / \mathrm{mL}$ each of E. coli (experiment 1), Staph. aureus (experiment 2), or Strep. uberis (experiment 3; Table 1) for $24 \mathrm{~h}$ at $37^{\circ} \mathrm{C}$ (4 separate plastic jars with 30 $\mathrm{mL}$ each of the same bacterial suspension; see further). Rubber teats 5 to 8 were not immersed in bacterial suspensions and served as negative controls.

To verify the concentrations of the bacterial suspensions, $20 \mu \mathrm{L}$ of each suspension was used to produce a 10-fold dilution in a 96-well plate (Sigma-Aldrich, Overijse, Belgium). The dilutions were plated on tryptic soy blood agar (Thermo Scientific, Oxoid, Merelbeke, Belgium) and counted after $24 \mathrm{~h}$ of incubation at $37^{\circ} \mathrm{C}$.

After 24-h immersion of the rubber teats, the cotton plugs were removed with sterile tweezers and placed into 50-mL Falcon tubes (BD Bioscience, Erembodegem, Belgium) filled with $5 \mathrm{~mL}$ each of BHI medium, after which each tube was filled with another $25 \mathrm{~mL}$ of BHI medium and gently inverted for $1 \mathrm{~min}$. The BHI medium was then plated on tryptic soy blood agar and incubated for $24 \mathrm{~h}$ via a 10-fold dilution to detect bacterial growth. Additionally, after the cotton plug was removed, the exterior and interior of each rubber teat was swabbed with sterile cotton swabs to check for contamination with bacteria other than the reference isolates of E. coli, Staph. aureus, and Strep. uberis. These cotton swabs were plated on tryptic soy blood agar plates and incubated for $24 \mathrm{~h}$ at $37^{\circ} \mathrm{C}$.

Three different major mastitis pathogens were selected from the reference strain collection of the Mastitis and Milk Quality Research Unit, Ghent University, Belgium: E. coli ATCC 25922, Staph. aureus ATCC 25923, and Strep. uberis BAA-854. The Strep. uberis 
Piepers et al.: SHORT COMMUNICATION: EXTERNAL TEAT SEALANTS

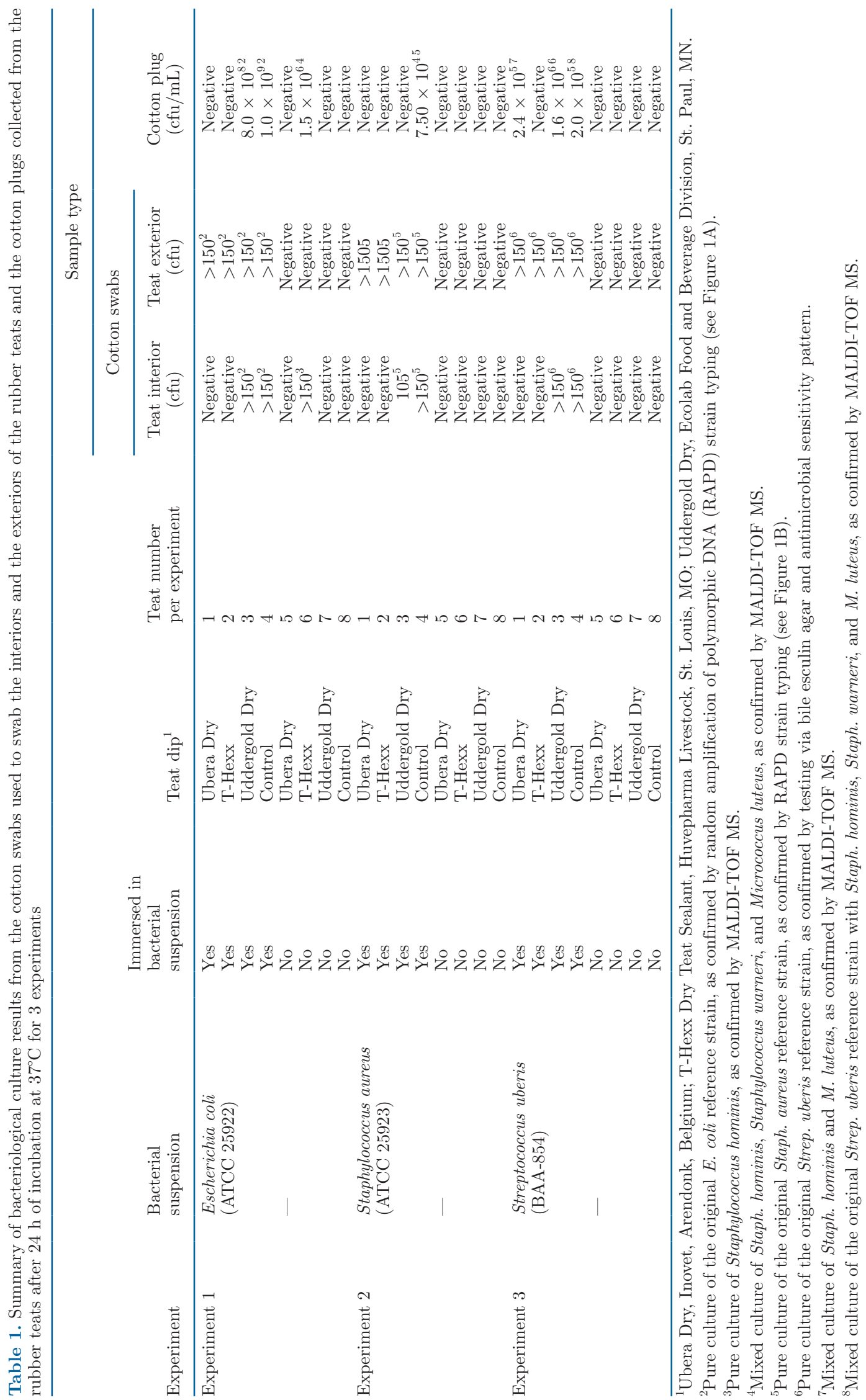


reference strain atypically hydrolyses esculin and forms thereby a dark brown or black complex on bile esculin agar (Thermo Scientific).

The mastitis isolates were initially stored at $-80^{\circ} \mathrm{C}$ (Microbank, Pro-Lab Diagnostics, Toronto, Canada). A growth curve was set up for each isolate by culturing the selected isolates on Columbia blood agar plates (Thermo Scientific), which were incubated for $24 \mathrm{~h}$ at $37^{\circ} \mathrm{C}$. A few colonies of the selected isolates were transferred with sterile cotton swabs into $2 \mathrm{~mL}$ of $0.85 \%$ $\mathrm{NaCl}$ tubes (bioMérieux, Brussels, Belgium) up to a concentration of $0.5 \mathrm{McF}$ arland. Then, $10 \mu \mathrm{L}$ of the 0.5-McFarland solution was transferred to $5 \mathrm{~mL}$ of BHI medium in 10-mL Falcon tubes with screw caps. In total, for each isolate, 24 Falcon tubes were prepared. The Falcon tubes were incubated at $37^{\circ} \mathrm{C}$ for $6 \mathrm{~h}$. An additional Falcon tube with $5 \mathrm{~mL}$ of sterile BHI medium was incubated and served as negative control. Based on the growth curve, $6 \mathrm{~h}$ of incubation at $37^{\circ} \mathrm{C}$ allowed a bacterial concentration of $>1.5 \times 10^{8} \mathrm{cfu} / \mathrm{mL}$ to be reached for each isolate while isolates were still in their late log phase. After incubation, all 24 Falcon tubes of each isolate were mixed into 1 sterile jar (total volume: $120 \mathrm{~mL}$ ) and then again divided into 4 small plastic jars, each containing $30 \mathrm{~mL}$ of bacterial suspension, as mentioned before. The final concentrations of the bacterial suspensions after $6 \mathrm{~h}$ of incubation at $37^{\circ} \mathrm{C}$ were $1.7 \times 10^{8} \mathrm{cfu} / \mathrm{mL}$ for $E$. coli, $1.4 \times 10^{9} \mathrm{cfu} / \mathrm{mL}$ for Staph. aureus, and $9 \times 10^{9} \mathrm{cfu} / \mathrm{mL}$ for Strep. uberis.

All bacterial isolates that were cultured during the experiments were stored in the freezer at $-80^{\circ} \mathrm{C}(\mathrm{Mi}-$ crobank, Pro-Lab Diagnostics) and afterward identified at the species level via MALDI-TOF MS, using the commercially available Bruker MALDI Biotyper system (Biotyper reference database version 4.0.0.1. with 5,627 entries; Bruker Daltonics Inc., Billerica, MA), expanded with a custom reference spectra database for the identification of bovine-associated non-aureus staphylococci (Cameron et al., 2018).

Random amplification of polymorphic DNA (RAPD-)PCR was used for strain-typing of E. coli ATCC 25922, Staph. aureus ATCC 25923, and the isolates collected from the cotton plugs or from the cotton swabs that were used to swab the interiors and exteriors of the rubber teats during the experiments. The RAPD-PCR was performed as described by Gurjar et al. (2012) with some modifications. Isolates of the same experiment were analyzed in the same PCR. For Strep. uberis BAA-854 and the Strep. uberis isolates recovered during the experiments, no RAPD was performed, in the absence of a functional standard operating procedure. Nonetheless, the isolates were checked for positive results of a bile esculin agar test, a typical trait of Strep. uberis BAA-854.The susceptibility to several antimicrobial compounds was tested using the KirbyBauer disk diffusion method (Supré et al., 2014): oxacillin $(1 \mu \mathrm{g})$, sulfonamide and trimethoprim combination (3.75 and $1.25 \mu \mathrm{g})$, cefazolin $(30 \mu \mathrm{g})$, cefoxitine $(30 \mu \mathrm{g})$, gentamycin $(250 \mu \mathrm{g})$, tetracycline $(30 \mu \mathrm{g})$, tylosin $(150$ $\mu \mathrm{g})$, and penicillin (1 IU). After $24 \mathrm{~h}$ of incubation at $37^{\circ} \mathrm{C}$, the inhibition zone diameters were evaluated according to clinical breakpoints provided by the Clinical and Laboratory Standards Institute (CLSI) to identify antimicrobial resistance, as described by Supré et al. (2014). As a result, the antimicrobial sensitivity patterns of the different Streptococcus uberis isolates could be compared.

All 3 external teat sealants adhered well to the rubber teats. However, adherence capacity under in vitro conditions in the current experiments does not necessarily equal adherence capacity in vivo - all the more so because adherence capacity and duration of adherence appear to depend on herd- and cow-management factors such as changing the ration to reduce milk production before drying off, level of milk yield before dry-off, and housing type (Lim et al., 2007b). A field study is needed to evaluate adherence capacity and duration of adherence in vivo. In fact, the only similarity between the rubber calf-feeding nipples used in this study and bovine teats is their conical shape and the constructed opening. Still, the shape of the physical structure is only 1 of many factors - including dermal moisture, $\mathrm{pH}$, and temperature - potentially determining the adherence and persistence capacity of an external teat sealant. Investigation of the adherence and duration of the 3 external teat sealants, and the extent to which the rubber calf-feeding nipples compare with bovine teats for relevant physical traits, fell beyond the scope of this study. The main advantage of the proposed method is that the use of live animals can be avoided while a live bacterial challenge is conducted, representing a meaningful starting point for experimental model research in this area. Still, one should be aware that the proposed method has not yet been validated to predict the risk of new IMI under field conditions.

With 1 exception, all cotton plugs collected from the rubber teats that were not exposed to E. coli, Staph. aureus, or Strep. uberis (rubber teats 5 to 8) remained culture-negative. From the cotton plug collected from rubber teat 6 during the $E$. coli experiment, which was not dipped nor exposed to a bacterial suspension, a mixed culture of Staphylococcus hominis, Staphylococcus warneri, and Micrococcus luteus was isolated (Table 1). Both Staph. hominis and Staph. warneri are common commensal organisms found among the skin flora of humans and animals (Kloos and Musselwhite, 1975). 
A.

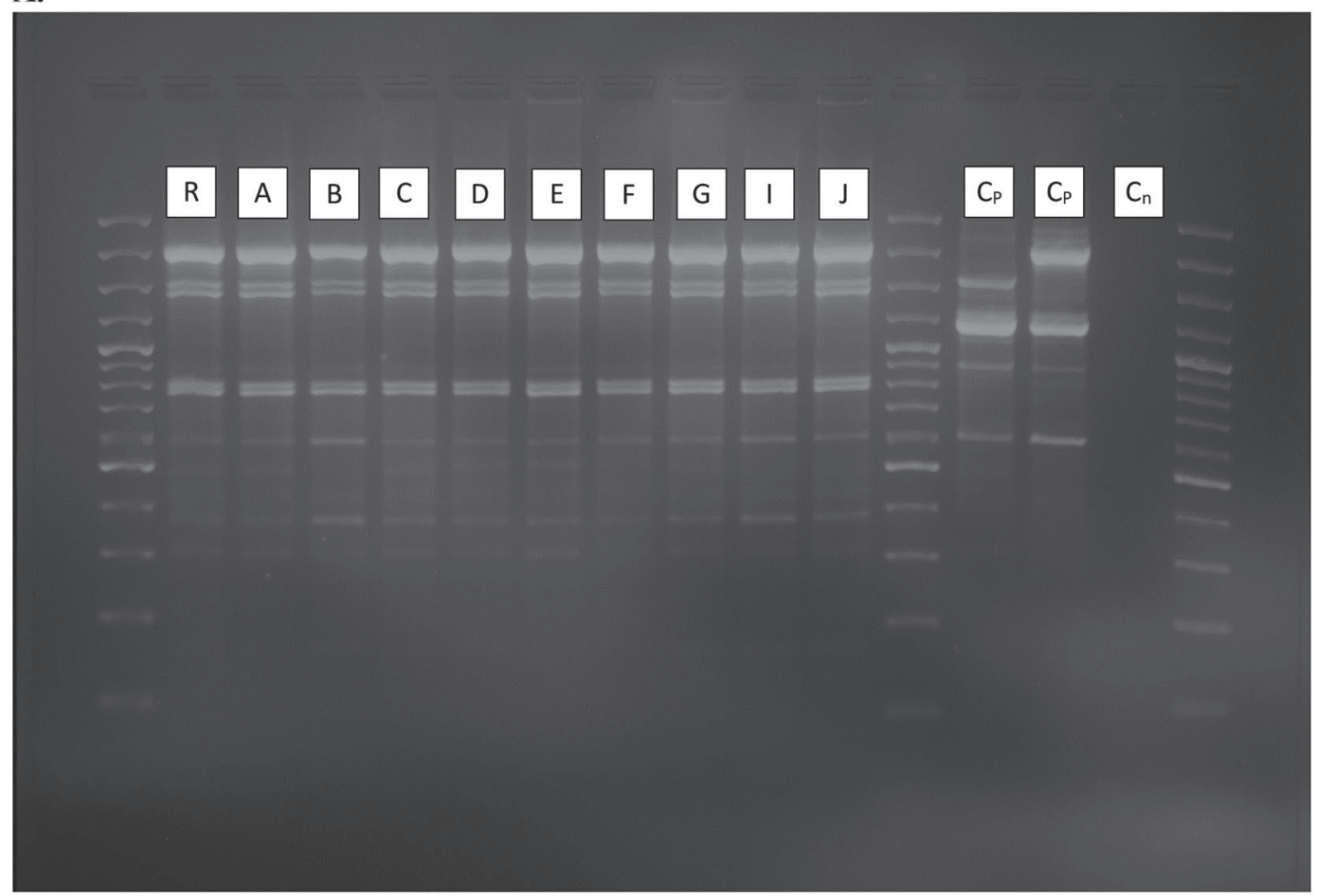

B.

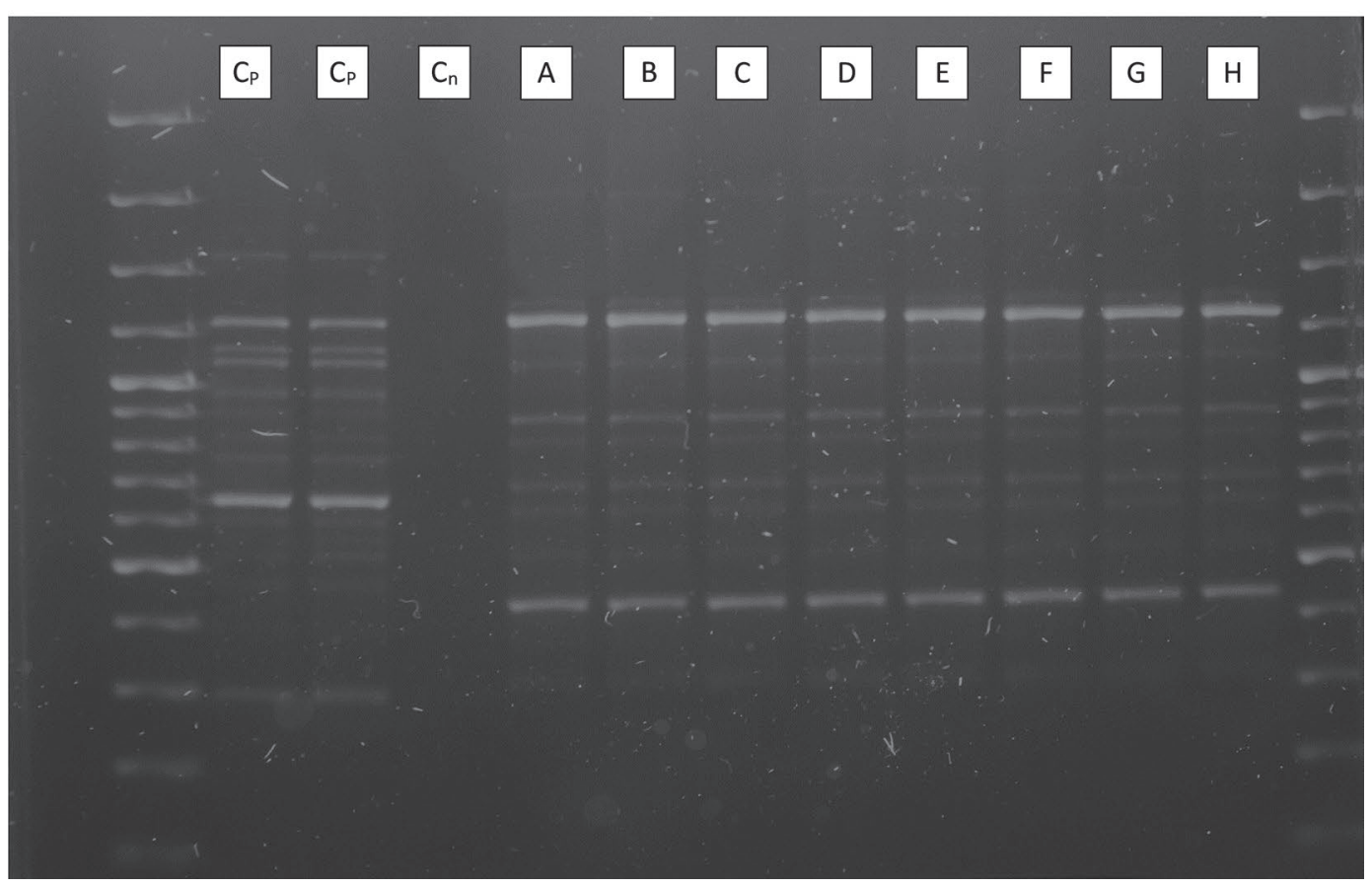

Figure 1. (A) Random amplification of polymorphic DNA (RAPD)-PCR strain typing of Escherichia coli isolates. R = original E. coli reference strain recovered from the Microbank vial (Pro-Lab Diagnostics, Toronto, Canada); A = original E. coli reference strain from the bacterial suspension in which the teats were immersed; $\mathrm{B}$ through $\mathrm{E}=E$. coli isolates from the exteriors of rubber teats 1 through $4 ; \mathrm{F}$ and $\mathrm{G}=E$. coli isolates from interiors of rubber teats 3 and $4 ; \mathrm{I}$ and $\mathrm{J}=E$. coli isolates from the cotton plugs collected from teats 3 and $4 ; \mathrm{C}_{\mathrm{p}}=2$ positive control strains of E. coli, as confirmed via MALDI-TOF MS; and $\mathrm{C}_{\mathrm{n}}=$ negative control. (B) RAPD strain-typing of Staphylococcus aureus isolates. A $=$ original Staph. aureus reference strain from the bacterial suspension in which the teats were immersed; B through E $=$ Staph. aureus isolates from the exteriors of rubber teats 1 through 4, respectively, after swabbing; $\mathrm{F}$ and $\mathrm{G}=$ Staph. aureus isolates from the interiors of rubber teats 3 and 4 after swabbing; $\mathrm{H}=$ Staph. aureus isolates from the cotton plug collected from teat $4 ; \mathrm{C}_{\mathrm{p}}=2$ positive control strains of Staph. aureus, as confirmed via MALDI-TOF MS; and $\mathrm{C}_{\mathrm{n}}=$ negative control. 
In some studies, these bacteria have been isolated from bovine milk (Vanderhaeghen et al., 2015). The isolation of the mixed culture of Staph. hominis, Staph. warneri, and M. luteus is most probably due to contamination from the hands, despite gloves being worn and disinfected throughout the experiments.

Of the rubber teats that were exposed to the major mastitis pathogens, all cotton plugs collected from those dipped with Ubera Dry and T-Hexx Dry remained culture-negative for the mastitis pathogen they were exposed to (Table 1). The cotton plugs collected from the rubber teats that were not sealed with an external teat sealant, which served as positive controls, became culture-positive for the same strain of the mastitis pathogens they were exposed to, as confirmed by strain typing (Figure 1). The culture of the cotton plug collected from rubber teat 4 (positive control) in experiment 3 consisted of a mixed culture of the Strep. uberis reference strain (as confirmed by the same antimicrobial resistance patterns) with Staph. hominis, Staph. warneri, and M. luteus, as was the case for rubber teat 6 in experiment 1 (Table 1). Despite the fact that sterile gloves were worn and regularly disinfected during the experiment, contamination cannot be excluded. The cotton plugs of the rubber teats that were sealed with Uddergold Dry and exposed to E. coli and Strep. uberis became culture-positive for the same E. coli and Strep. uberis strains, respectively, whereas the cotton plug of the rubber teat that was sealed with Uddergold Dry and exposed to Staph. aureus (rubber teat 3 ) in experiment 2 remained culture-negative.

Similar results to those derived from the cotton plugs were obtained from the cotton swabs used for swabbing the interiors and exteriors of the rubber teats (Table 1 ). Remarkably, although the cotton plug collected from rubber teat 3 (treated with Uddergold Dry) in experiment 2 remained culture-negative for Staph. aureus, the cotton swab used to swab the interior of the rubber teat was culture-positive for the same strain of Staph. aureus (Figure 1B).

As mentioned, strain typing confirmed that all recovered E. coli isolates belonged to the E. coli reference strain (Figure 1A). The same was true for the Staph. aureus isolates (Figure 1B). For Strep. uberis, all isolates were positive on the bile esculin agar, as was the case for the reference Strep. uberis strain. All isolates showed the same antimicrobial sensitivity pattern as that of the reference Strep. uberis strain. All isolated Strep. uberis strains showed resistance against gentamycin and were intermediately resistant to the combination of trimethoprim and sulfonamide. These results strongly indicate that the isolates collected from the cotton plugs and those from the cotton swabs were identical to the Strep. uberis reference strain.

It is important to note that the proposed method has not yet been validated as a method to predict either the adherence and duration of the external teat sealants or the risk of IMI when these sealants are used under in vivo conditions. However, given the overnight incubation at $37^{\circ} \mathrm{C}$ in rich $\mathrm{BHI}$ medium, the high dose of bacteria the rubber teats were exposed to, the open non-contractile teat end, and the high bacterial growth on the cotton plugs collected from the positive controls, it can be anticipated that the barrier characteristics of Ubera Dry and T-Hexx are stronger in preventing bacterial penetration of Escherichia coli, Staph. aureus, and Strep. uberis than the ones of Uddergold Dry.

In conclusion, Ubera Dry showed comparable and superior barrier performance against the penetration of E. coli, Staph. aureus, and Strep. uberis compared with T-Hexx Dry and Uddergold Dry, respectively, under in vitro conditions using rubber calf-feeding nipples. A large-scale longitudinal clinical trial is needed before any definite conclusions can be drawn as to the adherence, duration of adherence, barrier performance, and efficacy in protection against IMI of the 3 external teat sealants under field conditions.

\section{ACKNOWLEDGMENTS}

The research in this study was financially supported by Inovet. The authors have not stated any conflicts of interest.

\section{REFERENCES}

Bradley, A. J., S. De Vliegher, M. J. Green, P. Larrosa, B. Payne, E. S. van de Leemput, O. Samson, D. Valckenier, T. Van Werven, H. W. Waldeck, V. White, and L. Goby. 2015. An investigation of the dynamics of intramammary infections acquired during the dry period on European dairy farms. J. Dairy Sci. 98:6029-6047. https: //doi.org/10.3168/jds.2014-8749.

Bradley, A. J., and M. J. Green. 2010. Managing dry cows to optimize udder health part I: Understanding mammary gland susceptibility and the importance of the dry period in mastitis epidemiology. Ir. Vet. J. 63:384-387.

Cameron, M., J. Perry, J. R. Middleton, M. Chaffer, J. Lewis, and G. P. Keefe. 2018. Short communication: Evaluation of MALDI-TOF mass spectrometry and a custom reference spectra expanded database for the identification of bovine-associated coagulase-negative staphylococci. J. Dairy Sci. 101:590-595. https://doi.org/10.3168/ jds.2017-13226.

Godden, S., P. Rapnicki, S. Stewart, J. Fetrow, A. Johnson, R. Bey, and R. Farnsworth. 2003. Effectiveness of an internal teat seal in the prevention of new intramammary infections during the dry and early-lactation periods in dairy cows when used with a dry cow intramammary antibiotic. J. Dairy Sci. 86:3899-3911. https://doi .org/10.3168/jds.S0022-0302(03)73998-8.

Gurjar, A., G. Gioia, Y. Schukken, F. Welcome, R. Zadoks, and P. Moroni. 2012. Molecular diagnostics applied to mastitis problems on 
dairy farms. Vet. Clin. North Am. Food Anim. Pract. 28:565-576. https://doi.org/10.1016/j.cvfa.2012.07.011.

Halasa, T., O. Osteras, H. Hogeveen, T. van Werven, and M. Nielen. 2009. Meta-analysis of dry cow management for dairy cattle. Part 1: Protection against new intramammary infections. J. Dairy Sci. 92:3134-3149. https://doi.org/10.3168/jds.2008-1740.

Kloos, W. E., and M. S. Musselwhite. 1975. Distribution and persistence of Staphylococcus and Micrococcus species and other aerobic bacteria on human skin. Appl. Microbiol. 30:381-385. https://doi .org/10.1128/AEM.30.3.381-395.1975.

Lim, G. H., D. F. Kelton, K. E. Leslie, L. L. Timms, C. Church, and R. T. Dingwell. 2007b. Herd management factors that affect duration and variation of adherence of an external teat sealant. J. Dairy Sci. 90:1301-1309. https://doi.org/10.3168/jds.S0022 -0302(07)71618-1.

Lim, G. H., K. E. Leslie, D. F. Kelton, T. F. Duffield, L. L. Timms, and R. T. Dingwell. 2007a. Adherence and efficacy of an external teat sealant to prevent new intramammary infections in the dry period. J. Dairy Sci. 90:1289-1300. https://doi.org/10.3168/jds .S0022-0302(07)71617-X.

Smith, K. L., D. A. Todhunter, and P. S. Schoenberger. 1985. Environmental pathogens and intramammary infections during dry period. J. Dairy Sci. 68:402-417. https://doi.org/10.3168/jds.S0022 -0302(85)80838-9.

Supré, K., K. Lommelen, and L. De Meulemeester. 2014. Antimicrobial susceptibility and distribution of inhibition zone diameters of bovine mastitis pathogens in Flanders, Belgium. Vet. Microbiol. 171:374-381. https://doi.org/10.1016/j.vetmic.2014.02.045.

Vanderhaeghen, W., S. Piepers, F. Leroy, E. Van Coillie, F. Haesebrouck, and S. De Vliegher. 2015. Identification, typing, ecology, and epidemiology of coagulase-negative staphylococci associated with ruminants. Vet. J. 203:44-51. https://doi.org/10.1016/j.tvjl 2014.11.001. 